\title{
A Ca ${ }^{2+}$-Independent Receptor for $\alpha$-Latrotoxin, CIRL, Mediates Effects on Secretion via Multiple Mechanisms
}

\author{
Mary A. Bittner, ${ }^{1}$ Valery G. Krasnoperov, ${ }^{3}$ Edward L. Stuenkel, ${ }^{2}$ Alexander G. Petrenko, ${ }^{3}$ and Ronald W. Holz ${ }^{1}$ \\ Departments of ${ }^{1}$ Pharmacology and ${ }^{2}$ Physiology, The University of Michigan Medical School, Ann Arbor, Michigan 48109, \\ and ${ }^{3}$ Department of Pharmacology, New York University Medical Center, New York, New York 10016
}

\begin{abstract}
$\alpha$-Latrotoxin ( $\alpha$-Ltx), a component of black widow spider venom, stimulates secretion from nerve terminals and from PC12 cells. In this study we examine the effects of expression of a newly cloned $\mathrm{Ca}^{2+}$-independent receptor for $\alpha$-Ltx (CIRL) on secretion from bovine chromaffin cells. We first characterized the effect of $\alpha$-Ltx on secretion from untransfected cells. $\alpha$-Ltx, by binding in a $\mathrm{Ca}^{2+}$-independent manner to an endogenous receptor, causes subsequent $\mathrm{Ca}^{2+}$-dependent secretion from intact cells. The stimulation of secretion is correlated with $\mathrm{Ca}^{2+}$ influx caused by the toxin. In permeabilized cells in which the $\mathrm{Ca}^{2+}$ concentration is regulated by buffer, $\alpha$-Ltx also enhances $\mathrm{Ca}^{2+}$-dependent secretion, indicating a direct role of
\end{abstract}

The protein toxin $\alpha$-latrotoxin ( $\alpha$-Ltx), a component of black widow spider venom, has long been recognized for its ability to cause the release of neurotransmitter at the neuromuscular junction (Longenecker et al., 1970; Pumplin and Reese, 1977; Fesce et al., 1986). More recently, its effects on secretion in synaptosomes (Meldolesi et al., 1984; McMahon et al., 1990), cultured hippocampal neurons (Capogna et al., 1996), and neuroendocrine PC12 cells (Meldolesi et al., 1983; Rosenthal et al., 1990) have been investigated. Three reports indicate that it also has effects in chromaffin cells (Surkova, 1994; Barnett et al., 1996; Krasnoperov et al., 1997). At the neuromuscular junction neither binding nor neurotransmitter release requires extracellular $\mathrm{Ca}^{2+}$, provided that $\mathrm{Mg}^{2+}$ is present, although the magnitude of both is increased by adding $\mathrm{Ca}^{2+}$. In the absence of $\mathrm{Ca}^{2+}$, endocytic recycling of vesicular membrane is blocked, and the presynaptic terminal becomes swollen and depleted of vesicles (Ceccarelli and Hurlbut, 1980). $\mathrm{Ca}^{2+}$ supports endocytosis and additional rounds of transmitter release. Studies in vitro have demonstrated that the toxin molecule can form large-conductance pores in the lipid bilayer, which allow the passage of cations (Finkelstein et al., 1976). It is unclear whether the increased $\mathrm{Ca}^{2+}$ permeability

\footnotetext{
Received Nov. 26, 1997; revised Jan. 23, 1998; accepted Feb. 3, 1998.

This work was supported in part by National Science Foundation Grant IBN 9008685 (to M.A.B.); by Public Health Service Grants R01DK27959 (to R.W.H.), R01NS35098, and R01NS34937 from the National Institute of Neurological Diseases and Stroke; and by a pilot project from Center Grant ES00260 from the National Institute of Environmental Health Sciences (to A.G.P.). We thank Drs. Craig Logsdon, Richard Neubig, and Ian Macara for their kind gifts of bombesin receptor, $\alpha_{2 \mathrm{~A}}$ adrenergic receptor, and GFP plasmids, respectively. We also thank Ada Beef, Ada, MI, for its assistance in procuring bovine adrenal glands. This work is dedicated to the memory of Dr. Alex Mauro, who was a model for enthusiasm and dedication in science and who introduced one of us (R.W.H.) to the extraordinary effects of black widow spider venom at the neuromuscular junction.

Correspondence should be addressed to Dr. Mary A. Bittner, Department of Pharmacology, M 1301 MSRB III, University of Michigan Medical School, Ann Arbor, MI 48109.

Copyright (ㄷ) 1998 Society for Neuroscience $\quad 0270-6474 / 98 / 182914-09 \$ 05.00 / 0$
}

the endogenous receptor in the secretory pathway. Expression of CIRL increased the sensitivity of intact and permeabilized cells to the effects of $\alpha$-Ltx, demonstrating that this protein is functional in coupling to secretion. Importantly, in the absence of $\alpha$-Ltx, the expression of CIRL specifically inhibited the ATPdependent component of secretion in permeabilized cells without affecting the ATP-independent secretion. This suggests that this receptor modulates the normal function of the regulated secretory pathway and that $\alpha$-Ltx may act by reversing the inhibitory effects of the receptor.

Key words: $\alpha$-latrotoxin; secretion; exocytosis; catecholamine; chromaffin cell; secretion kinetics

associated with $\alpha$-Ltx is a direct consequence of the pore-forming ability of the toxin or is attributable to the activation of an $\alpha$-Ltx receptor.

In synaptosomes and at the neuromuscular junction, $\alpha$-Ltx binds to protein(s) on the cell surface in both a $\mathrm{Ca}^{2+}$-dependent and $\mathrm{Ca}^{2+}$-independent manner (Rosenthal et al., 1990). $\mathrm{Ca}^{2+}$. dependent binding of $\alpha$-Ltx is mediated by neurexin $1 \alpha$, a member of a large family of neuronal glycoproteins (Petrenko et al., 1990, 1993; Ushkaryov et al., 1992), the function of which has yet to be determined. A different protein that binds $\alpha$-Ltx in the absence of $\mathrm{Ca}^{2+}$ has been isolated (Davletov et al., 1996; Krasnoperov et al., 1996) and cloned recently (Krasnoperov et al., 1997; Lelianova et al., 1997). Its function is the subject of this investigation.

In this study we examined the effects of $\alpha$-Ltx on secretion from primary cultured neuroendocrine cells. $\alpha$-Ltx was an extremely potent secretagogue, causing secretion in both intact and digitonin-permeabilized chromaffin cells at subnanomolar concentrations. Transiently expressing a newly cloned $\mathrm{Ca}^{2+}$. independent receptor for $\alpha$-Ltx (CIRL) from rat brain increased the sensitivity of both intact and permeabilized chromaffin cells to the toxin. In the absence of $\alpha$-Ltx, overexpressed CIRL also inhibited secretion in permeabilized cells, suggesting that this receptor may play an inhibitory role in the secretory pathway.

\section{MATERIALS AND METHODS}

Plasmids. Human growth hormone (hGH) was expressed with pXGH5, which is under the control of the mouse metallothionein I promoter (Selden et al., 1986). Incubation with a heavy metal was not necessary to obtain adequate hGH expression. The plasmid encoding CIRL (pCDR7) is described in Krasnoperov et al. (1997). A plasmid encoding the $\alpha_{2 \mathrm{~A}}$ adrenergic receptor (pCMV4-TAG- $\alpha_{2 A}-\mathrm{AR}$ ) that was described in Keefer and Limbird (1993) was provided by R. Neubig, University of Michigan. The $1.4 \mathrm{~kb}$ mouse bombesin receptor (Battey et al., 1991) was subcloned (Tseng et al., 1995), then FLAG-tagged at the N terminus, and again subcloned into pcDNA3 in the laboratory of C. Logsdon, Univer- 
sity of Michigan. The plasmid (p7sGFP) encoding a mutant GFP(S65T) (Helm et al., 1995) was a gift of Dr. I. Macara, University of Virginia.

Transfection and cell culture. Bovine adrenal chromaffin cells were prepared and maintained in culture, as previously described (Bittner and Holz, 1992b), except that the medium used was DMEM/Ham's F-12. Cells for transfection were grown in 12-well plates (Costar, Cambridge, MA) and were transfected by calcium phosphate precipitate $14-18 \mathrm{hr}$ after plating (Wilson et al., 1996). Experimental (pCDR7; $3 \mu \mathrm{g} /$ well) and control (pCMVneo; $3 \mu \mathrm{g} /$ well) plasmids were each mixed with pXGH5 $(2 \mu \mathrm{g} /$ well) before the precipitates were generated. Previous work in the laboratory has demonstrated that this procedure ensures that $>95 \%$ of transfected cells express both hGH and the protein of interest (Ma et al., 1992; Wick et al., 1993; Holz et al., 1994; Chung et al., 1995; Bittner et al., 1996). The total amounts of hGH in cells with and without CIRL were comparable. Total hGH in CIRL-transfected cells averaged $108 \pm 5 \%$ of that in control (neo) cells ( $n=25$ separate experiments). hGH is stored in chromaffin granules and is released concomitantly with endogenous catecholamine by various secretagogues. Thus, hGH serves as a selective marker for secretion from transfected cells.

Human embryonic kidney (HEK)293 cells were plated at a density of $2.4 \times 10^{5}$ cells/well in 24-well plates and transfected with $0.25 \mathrm{ml}$ of serum- and antibiotic-free DMEM per well containing $2 \mu \mathrm{l}$ of Lipofectamine and $0.55 \mu \mathrm{g}$ of DNA. Medium containing $10 \%$ serum was added after $5 \mathrm{hr}$ and replaced by complete medium containing antibiotics and $10 \mu \mathrm{M}$ cytosine arabinoside after $24 \mathrm{hr}$.

Assays. Physiological salt solution (PSS) contained (in mM) $145 \mathrm{NaCl}$, 5.6 KCl, 5.6 glucose, 0.5 ascorbate, 15 HEPES, $\mathrm{pH} 7.4,2.2 \mathrm{CaCl}_{2}$, and $0.5 \mathrm{MgCl}_{2}$ unless otherwise indicated. The potassium glutamate solution (KGENP) used in permeabilized cell experiments contained (in mM) 139 potassium glutamate, 20 PIPES, pH 6.6, 2 MgATP, and either 5 EGTA and 5 nitrilotriacetic acid without $\mathrm{Ca}^{2+}$, or 5 EGTA and 5 nitrilotriacetic acid with various amounts of $\mathrm{CaCl}_{2}$ to yield buffered $\mathrm{Ca}^{2+}$ concentrations of 1-1000 $\mu \mathrm{M}$ (Bittner and Holz, 1992b). KGEP solution lacked nitrilotriacetic acid but was otherwise identical to KGENP. hGH was measured with a luminescent assay kit from Corning Nichols Institute Diagnostics (San Juan Capistrano, CA) (Bittner et al., 1996). Endogenous catecholamines were measured by spectrofluorometric assay (Dunn and Holz, 1983). Stimulated release is calculated as the amount of hGH released into the incubation medium divided by the total hGH (i.e., hGH released plus hGH remaining in the cells). Data are expressed as mean \pm SEM unless otherwise indicated. Significance was determined by Student's $t$ test. Error bars smaller than the symbols were omitted from the figures. Differences in the potency of various toxin batches and the biological variability of individual cell preparations probably account for small differences in potency between individual experiments.

Calcium measurements. Measurements of intracellular calcium were performed by monitoring the fluorescence of fura-2-loaded chromaffin cells, which were plated on glass coverslips. Chromaffin cells in $60 \mathrm{~mm}$ plastic dishes were transfected with plasmids for green fluorescent protein (GFP) and either pCDR7 or pCMVneo, with GFP serving as a marker for the transfected cells. After $24 \mathrm{hr}$ the cells were removed from the dishes with trypsin/versene and replated on glass coverslips. Loading of the cells was performed by incubation for $30 \mathrm{~min}$ at $37^{\circ} \mathrm{C}$ with $1 \mu \mathrm{M}$ fura-2 AM, followed by a 20-30 min incubation period to allow for AM ester cleavage. After loading, the coverglass containing the cells was placed into a holder that allowed for perfusion with selected PSS solutions. Dual-wavelength microspectrofluorometry similar to that described previously was used to monitor fura-2 fluorescence (Stuenkel and Nordmann, 1993). The wavelengths for the excitation and emission from GFP differ sufficiently from those of fura- 2 such that there is no contribution to or interference with the fura- 2 signal. Alternating excitation wavelengths of 340 and $380 \mathrm{~nm}$ and monitoring of emitted light at $500 \mathrm{~nm}$ were performed by a photomultiplier-based SPEX Industries AR-CM system (Edison, NJ). The fluorescence ratio (340:380) was converted to an intracellular calcium concentration by the equation of Grynkiewicz, Poenie, and Tsien (Grynkiewicz et al., 1985). An external standard calibration approach was used to determine the values of $R_{\min }, R_{\max }$, and $F_{\mathrm{o}} / F_{\mathrm{s}}$, which were $1.135,17.5$, and 3.54 , respectively. A $K_{\mathrm{D}}$ value of 224 $\mathrm{nm}$ was taken from the literature.

Materials. Reagents were received from the following sources: $\alpha$-latrotoxin, Petrenko et al. (1990) or Alomone Laboratories (Jerusalem, Israel); ${ }^{3} \mathrm{H}$-norepinephrine, Amersham (Arlington Heights, IL); digitonin, Fluka Chemical (Ronkonkoma, NY); fura-2 AM, Molecular Probes (Eugene, OR); Lipofectamine, Life Technologies (Grand Island, NY); collagenase B, Boehringer Mannheim (Indianapolis, IN); ampho-

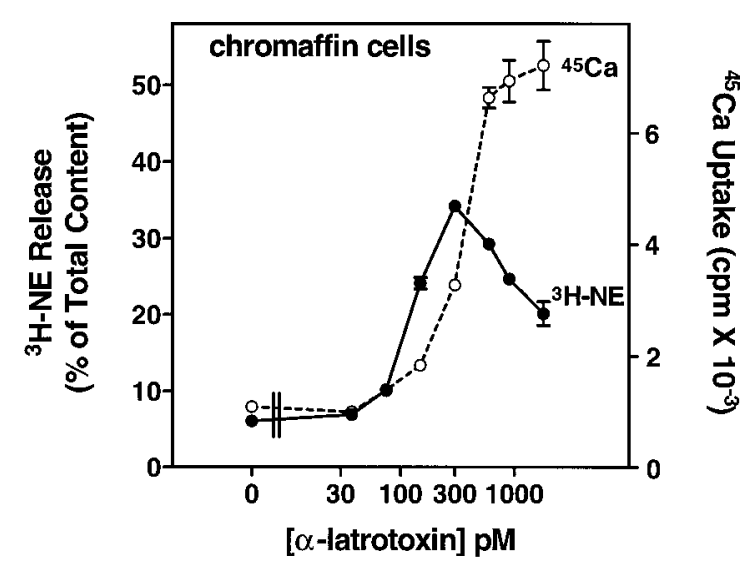

Figure 1. $\alpha$-Latrotoxin stimulates catecholamine secretion and $\mathrm{Ca}^{2+}$ uptake in cultured chromaffin cells. Monolayer cultures of bovine adrenal chromaffin cells were labeled with ${ }^{3} \mathrm{H}$-norepinephrine $\left({ }^{3} \mathrm{H}-\mathrm{NE}\right)$, rinsed, and incubated with the indicated concentrations of $\alpha$-Ltx in physiological saline without $\mathrm{Ca}^{2+}$ or $\mathrm{Mg}^{2+}$ and with $0.1 \mathrm{~mm}$ EGTA for 4 min. The toxin was removed, and the cells were incubated for $6 \mathrm{~min}$ in PSS containing $2.2 \mathrm{mM} \mathrm{Ca}^{2+}$ and $0.5 \mathrm{mM} \mathrm{Mg}^{2+}$. The incubation solution was removed, the cells were lysed with $1 \%$ Triton $X-100$, and the amount of ${ }^{3} \mathrm{H}-\mathrm{NE}$ was determined by liquid scintillation spectrometry; $n=3$ wells/ group. Parallel cultures that had not been labeled with ${ }^{3} \mathrm{H}-\mathrm{NE}$ also were incubated with $\alpha$-Ltx, followed by an incubation in PSS containing $2.2 \mathrm{~mm}$ $\mathrm{Ca}^{2+}, 0.5 \mathrm{~mm} \mathrm{Mg}{ }^{2+}$, and $3 \mu \mathrm{Ci} / \mathrm{ml}^{45} \mathrm{Ca}^{2+}$. After $4 \mathrm{~min}$, the cells were rinsed immediately three times in PSS, and the amount of ${ }^{45} \mathrm{Ca}^{2+}$ in the cells was determined by liquid scintillation spectrometry; $n=4$ wells/group.

tericin B (Fungizone), Gensia Laboratories (Irvine, CA); cell culture reagents, including gentamycin, penicillin/streptomycin, and DMEM/ F-12 medium, BioWhittaker (Walkersville, MD). All other reagents, including fetal bovine serum, were obtained from Sigma (St. Louis, MO).

\section{RESULTS}

Preliminary experiments demonstrated that $\alpha$-Ltx does not stimulate secretion from chromaffin cells in a $\mathrm{Ca}^{2+}$-free buffer containing a $\mathrm{Ca}^{2+}$ chelator, even when $\mathrm{Mg}^{2+}$ is present. Secretion can be stimulated by incubating chromaffin cells simultaneously with $\alpha$-Ltx and $\mathrm{Ca}^{2+}$ or by incubating cells with $\alpha$-Ltx in EGTAcontaining buffer before providing a $\mathrm{Ca}^{2+}$ stimulus. We chose to use the latter protocol in this study, because the analysis was less complicated when toxin binding was completed before the onset of secretion. The protocol ensured that only those receptors that bind $\alpha$-Ltx in the absence of $\mathrm{Ca}^{2+}$ were being studied. In a typical experiment the cells were exposed to $\alpha$-Ltx in PSS without $\mathrm{Mg}^{2+}$ or $\mathrm{Ca}^{2+}$ and with EGTA. After removal of the toxin, secretion was initiated in PSS containing both $\mathrm{Mg}^{2+}$ and $\mathrm{Ca}^{2+}$.

\section{Effect of $\alpha$-Ltx in intact chromaffin cells}

Incubation of bovine chromaffin cells with $\alpha$-Ltx in PSS with 0.1 mM EGTA and no $\mathrm{Mg}^{2+}$ or $\mathrm{Ca}^{2+}$, followed by incubation in PSS containing $2.2 \mathrm{mM} \mathrm{Ca}^{2+}$ and $0.5 \mathrm{mM} \mathrm{Mg}^{2+}$, caused a dosedependent release of catecholamine from chromaffin cells labeled with ${ }^{3} \mathrm{H}$-norepinephrine $\left({ }^{3} \mathrm{H}-\mathrm{NE}\right)$ (Fig. 1). Although the association of $\alpha$-Ltx with the cells occurred in EGTA-containing solution, secretion did not occur during the first incubation without $\mathrm{Ca}^{2+}$ and $\mathrm{Mg}^{2+}$ (data not shown) (but see also Fig. 3). Secretion was dependent on $\mathrm{Ca}^{2+}$ in the second incubation and was associated with $\mathrm{Ca}^{2+}$ influx, as measured by the uptake of ${ }^{45} \mathrm{Ca}^{2+}$. Even at $75 \mathrm{pm} \alpha$-Ltx, the increase in catecholamine secretion was associated with a measurable increase in ${ }^{45} \mathrm{Ca}^{2+}$ uptake. The dose-response curve for exocytosis was biphasic, with less secre- 

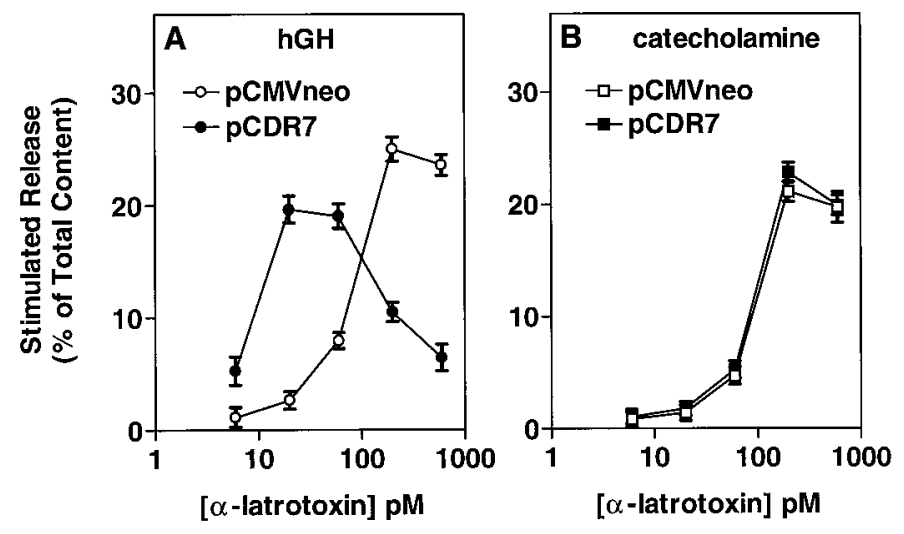

Figure 2. Expression of CIRL increases the sensitivity of intact chromaffin cells to stimulation by $\alpha$-Ltx. Chromaffin cells were transfected with plasmids for hGH (pXGH5) and either pCDR7, which encodes a newly cloned protein that binds $\alpha$-Ltx (CIRL), or pCMVneo (a control) by calcium phosphate precipitates, as described. After $4 \mathrm{~d}$ the cells were incubated with the indicated concentrations of $\alpha$-Ltx in PSS without $\mathrm{Ca}^{2+}$ or $\mathrm{Mg}^{2+}$ and with $0.1 \mathrm{~mm}$ EGTA. After $4 \mathrm{~min}$, the toxin was removed, and the cells were incubated for an additional $5 \mathrm{~min}$ in PSS containing $2.2 \mathrm{mM} \mathrm{Ca}$ and $0.5 \mathrm{~mm} \mathrm{Mg}$. The amounts of hGH $(A)$ and catecholamine $(B)$ released into the medium and the amounts remaining in the cells were determined as described; $n=4$ wells/group.

tion elicited above 300 pM $\alpha$-Ltx. This decrease in secretion did not result from an inactivation of $\mathrm{Ca}^{2+}$ influx, because ${ }^{45} \mathrm{Ca}^{2+}$ uptake continued to increase. It may be a consequence of excessive $\mathrm{Ca}^{2+}$ influx, because high $\mathrm{Ca}^{2+}$ concentrations can inhibit secretion from permeabilized chromaffin cells (Knight and Baker, 1982; Bittner and Holz, 1992b).

\section{Effect of a cloned $\alpha$-Ltx receptor on secretion and $\mathrm{Ca}^{2+}$ entry in intact cells}

In a previous study we determined that a newly cloned receptor for $\alpha$-Ltx termed CIRL can couple to secretion in chromaffin cells (Krasnoperov et al., 1997). Our first prediction was that expression of the CIRL protein would increase the number of $\alpha$-Ltx binding sites on the cells, thus rendering the cells more sensitive to the stimulatory effects of $\alpha$-Ltx. Chromaffin cells were cotransfected with a plasmid encoding hGH and with either a plasmid encoding CIRL (pCDR7) or a control plasmid (pCMVneo). Transiently expressed hGH is stored in secretory granules (Wick et al., 1993) and serves as a marker for regulated secretion from the small population of transfected cells. When cells transiently overexpressing the receptor were stimulated with various concentrations of $\alpha$-Ltx, there was a 10 -fold shift to the left in the concentration of $\alpha$-Ltx required to stimulate a maximal response, from 200 to $20 \mathrm{pm}$ (Fig. $2 A$ ). The maximal response to $\alpha$-Ltx in the cells transfected with CIRL was significantly lower than the maximal response in cells transfected with $\mathrm{pCMVneo}[p=$ 0.0025 (background not subtracted)]. Furthermore, the downward limb of the biphasic dose-effect curve in Figure 1 likewise was shifted to the left; secretion at the higher concentrations of $\alpha$-Ltx (200-600 pM) was much reduced by expression of CIRL. As expected, the dose-effect curve for catecholamine secretion (which measures secretion from all cells in the culture, the bulk of which are not transfected) was unchanged (Fig. $2 B$ ).

In Figure 1 we demonstrated that secretion stimulated by $\alpha$-Ltx strongly correlated with the influx of extracellular $\mathrm{Ca}^{2+}$. We asked whether extracellular $\mathrm{Ca}^{2+}$ is required for the toxin to stimulate secretion in chromaffin cells that overexpress CIRL
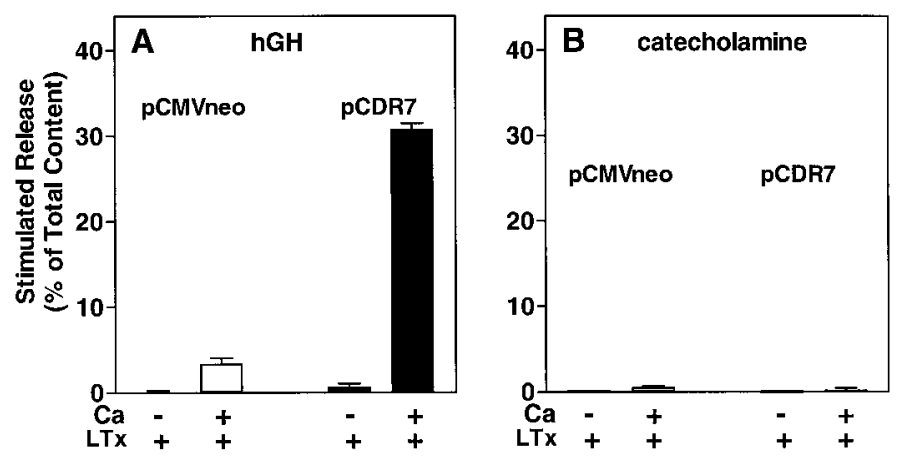

Figure 3. Secretion stimulated by $\alpha$-latrotoxin requires extracellular $\mathrm{Ca}^{2+}$. Chromaffin cells were transfected with plasmids for $\mathrm{hGH}$ (pXGH5) and either pCDR7 or pCMVneo, as in Figure 2. After $4 \mathrm{~d}$ the cells were incubated for $10 \mathrm{~min}$ with or without $26 \mathrm{pM} \alpha$-Ltx in either PSS without $\mathrm{Ca}^{2+}$ or $\mathrm{Mg}^{2+}$ and with 0.2 mM EGTA (indicated as $-\mathrm{Ca}$ ), or PSS containing $2.2 \mathrm{mM} \mathrm{Ca}^{2+}$ and $0.5 \mathrm{mM} \mathrm{Mg}^{2+}$ (indicated as $+\mathrm{Ca}$ ). The amounts of hGH $(A)$ and catecholamine $(B)$ released into the medium and the amounts remaining in the cells were determined as described; $n=$ 4 wells/group.

(Fig. 3). In cells expressing only the endogenous receptor (Fig. $3 A$, unfilled bars), 26 pM $\alpha$-Ltx (a markedly suboptimal concentration) was unable to elicit secretion in PSS without $\mathrm{Mg}^{2+}$ or $\mathrm{Ca}^{2+}$, and with EGTA. Expression of CIRL rendered the cells sensitive to $26 \mathrm{pm} \alpha$-Ltx (Fig. 3 A, filled bars), but secretion remained entirely dependent on external $\mathrm{Ca}^{2+}$. A higher concentration of $\alpha$-Ltx ( $260 \mathrm{pm})$ did not cause significant secretion in the absence of $\mathrm{Ca}^{2+}$, even in the CIRL-transfected cells (data not shown). Catecholamine secretion (essentially a measure of the secretory response of nontransfected cells in the cultures) was not stimulated by 26 pм $\alpha$-Ltx (Fig. 3B).

On the basis of these results, we would expect that the interaction of $\alpha$-Ltx with the cloned receptor should result in $\mathrm{Ca}^{2+}$ entry. We were able to demonstrate this in two ways: (1) by measuring ${ }^{45} \mathrm{Ca}$ uptake in HEK293 cells transfected with CIRL (HEK293 cells lack an endogenous $\alpha$-Ltx receptor) and (2) by measuring intracellular $\mathrm{Ca}^{2+}$ levels in individual chromaffin cells transfected with or without CIRL.

First, HEK293 cells transfected with or without CIRL were incubated with various concentrations of $\alpha$-Ltx in PSS without divalent cations and with EGTA for $4 \mathrm{~min}$ and then were incubated with PSS containing ${ }^{45} \mathrm{Ca}^{2+}$ (Fig. 4A). Incubation of CIRL-expressing cells with $250 \mathrm{pm}$ or $1 \mathrm{nM} \alpha$-Ltx caused a profound increase in ${ }^{45} \mathrm{Ca}^{2+}$ uptake but had no effect on ${ }^{45} \mathrm{Ca}^{2+}$ uptake in cells without CIRL.

The presence of endogenous $\alpha$-Ltx receptors combined with low transfection efficiency precluded the use of ${ }^{45} \mathrm{Ca}^{2+}$ to measure directly the changes in $\mathrm{Ca}^{2+}$ influx in chromaffin cells transfected with CIRL. Instead, we examined the ability of various concentrations of $\alpha$-Ltx to cause an increase in intracellular free $\mathrm{Ca}^{2+}$, as measured by fura- 2 in single cells transfected with (Fig. $4 C$ ) or without CIRL (Fig. 4B). Coexpressed GFP was used as a marker for the transfected cells. Cells without overexpressed CIRL showed no increase in cytosolic $\mathrm{Ca}^{2+}$ when they were perfused with 26 pM $\alpha$-Ltx (Fig $4 B, n=3$ ), whereas cells expressing CIRL all exhibited a large, sustained increase in cytosolic $\mathrm{Ca}^{2+}($ mean $=296 \pm 44 \mathrm{~nm})$ when challenged with 26 pM $\alpha$-Ltx (Fig. 4C, $n=4)$. Cells with or without transfected CIRL responded to a subsequent application of 260 pM $\alpha$-Ltx, increasing their mean cytosolic $\mathrm{Ca}^{2+}$ concentrations to $766 \pm 121$ and 
A. HEK293 cells

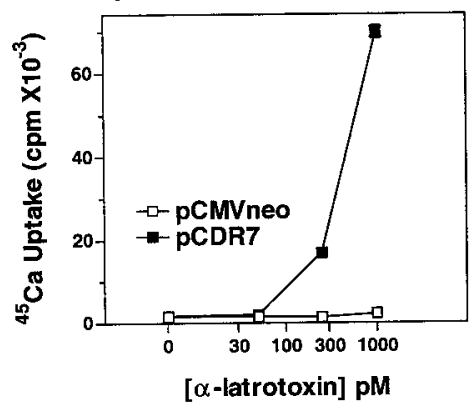

B. control chromatfin cell

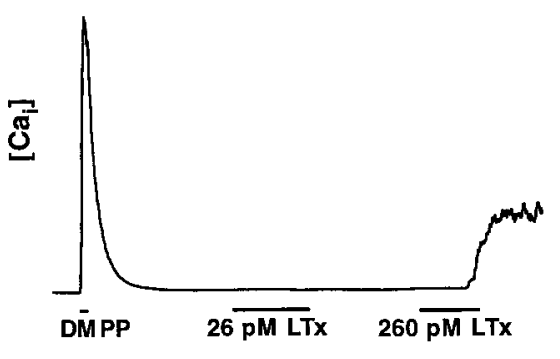

C. CIRL transfected chromaffin cell

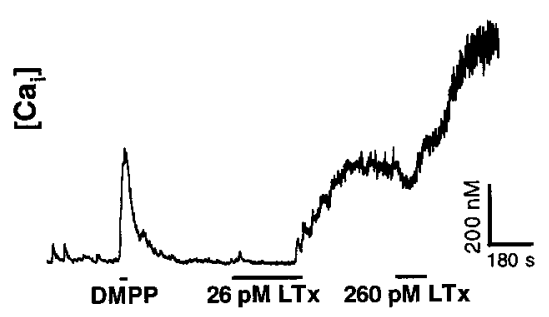

Figure 4. CIRL supports both $\mathrm{Ca}^{2+}$ entry and the sustained elevation of intracellular $\mathrm{Ca}^{2+}$ elicited by $\alpha$-latrotoxin. $A$, HEK293 cells were transfected with plasmids for green fluorescent protein (GFP) and either pCDR7 (CIRL) or pCMVneo by Lipofectamine, as described. After $2 \mathrm{~d}$ the cells were incubated with the indicated concentrations of $\alpha$-Ltx in physiological saline without $\mathrm{Ca}^{2+}$ or $\mathrm{Mg}^{2+}$ and with $0.2 \mathrm{~mm}$ EGTA for 4 min. The incubation with toxin was followed by a $6 \mathrm{~min}$ incubation in PSS containing $2.2 \mathrm{mM} \mathrm{Ca}^{2+}, 0.5 \mathrm{mM} \mathrm{Mg}^{2+}$, and $1 \mu \mathrm{Ci} / \mathrm{ml}^{45} \mathrm{Ca}^{2+}$. The cells were rinsed immediately three times with PSS without ${ }^{45} \mathrm{Ca}^{2+}$, and the amount of ${ }^{45} \mathrm{Ca}^{2+}$ in the cells was determined by liquid scintillation spectrometry; $n=5$ wells/group. $B$, $C$, Chromaffin cells were transfected with plasmids for GFP and either pCDR7 or pCMVneo, with GFP serving as a marker for the transfected cells. Cultures were loaded with $1 \mu \mathrm{M}$ fura-2 AM and subsequently were perfused with a $10 \mu \mathrm{M}$ concentration of a nicotinic agonist (dimethylphenylpiperazinium, DMPP), followed by the indicated concentrations of $\alpha$-Ltx in PSS. The duration of each agonist application is indicated by a horizontal bar. Intracellular $\mathrm{Ca}^{2+}$ levels were obtained as described in Materials and Methods. Following are the mean resting Ca ${ }^{2+}$ levels: $-\mathrm{CIRL}, 56 \pm 11 \mathrm{nM}, n=$ $3 ;+$ CIRL, $45 \pm 7 \mathrm{nM}, n=4$.

$395 \pm 204 \mathrm{~nm}$, respectively. These data are consistent with the results from secretion experiments (e.g., Fig. 3) in which $26 \mathrm{pm}$ $\alpha$-Ltx elicited excellent secretion from cells overexpressing CIRL but had little effect on cells that lacked the transfected receptor. These experiments demonstrate that the newly cloned CIRL can function appropriately as an $\alpha$-Ltx receptor in situ.

We also noted that the effect of $\alpha$-Ltx to increase cytosolic $\mathrm{Ca}^{2+}$ was delayed in comparison to the response to the nicotinic agonist dimethylphenylpiperazinium (DMPP). Chromaffin cells typically respond to DMPP in $<1 \mathrm{sec}$, whereas the mean response times for $\alpha$-Ltx included the following: +CIRL, $26 \mathrm{pm} \alpha$-Ltx, $185 \pm 34 \mathrm{sec} ;+$ CIRL, 260 pM $\alpha$-Ltx, $73 \pm 7 \mathrm{sec}$; -CIRL, $260 \mathrm{pm}$ $\alpha$-Ltx, $143 \pm 15$ sec. Thus, the response times of the transfected receptor and the endogenous receptor were similar.

\section{Effect of $\alpha$-Ltx and transiently expressed CIRL on secretion in permeabilized chromaffin cells}

To determine whether $\alpha$-Ltx modifies the secretory response at a step after $\mathrm{Ca}^{2+}$ entry, we investigated the effects of $\alpha$-Ltx on secretion from digitonin-permeabilized cells. Intact (nontransfected) chromaffin cells were incubated with $\alpha$-Ltx in the absence of divalent ions $(+0.2 \mathrm{~mm}$ EGTA) for 4 min before permeabilization. The cells subsequently were permeabilized in the absence of $\alpha$-Ltx, and secretion was stimulated with $30 \mu \mathrm{M} \mathrm{Ca}{ }^{2+}$. $\alpha$-Latrotoxin caused a dose-dependent increase in $\mathrm{Ca}^{2+}$ stimulated secretion (Fig. $5 A$ ). The enhancement was substantial (>50\% at $1 \mathrm{~nm} \alpha$-Ltx) and occurred over the range of $\alpha$-Ltx concentrations that caused secretion in intact cells. However, unlike the situation in intact cells, the channel-forming property of $\alpha$-Ltx cannot explain its effect on secretion, because after digitonin treatment the cell membrane is freely permeable to $\mathrm{Ca}^{2+}$. This effect on secretion in permeabilized cells represents a second function of $\alpha$-Ltx that is distinct from the changes in $\mathrm{Ca}^{2+}$ permeability seen in intact cells.

On the basis of the ability of overexpressed CIRL to render intact cells more sensitive to $\alpha$-Ltx, we might expect to see increased sensitivity to $\alpha$-Ltx in permeabilized cells expressing CIRL. Chromaffin cells were transfected with and without CIRL and were incubated immediately before permeabilization with a concentration of $\alpha$-Ltx (50 pM) that had little effect in nontrans- fected cells (see Fig. 1) but strongly stimulated hGH secretion in intact cells expressing CIRL (see Fig. $2 A$ ). Again, permeabilized cells with overexpressed receptor responded more vigorously to a low concentration of $\alpha$-Ltx than cells transfected with control plasmid (Fig. 5B). $\mathrm{Ca}^{2+}$-stimulated secretion in CIRLtransfected cells was increased by $72 \%$ by $50 \mathrm{pM} \alpha$-Ltx; cells that received the control plasmid pCMVneo required $400 \mathrm{pm}$ toxin to elicit a similar degree of enhancement (63\%) (data not shown). Little or no enhancement of catecholamine secretion was seen with $50 \mathrm{pm} \alpha$-Ltx (Fig. 5C). The data indicate that the same protein that mediates the effects of $\alpha$-Ltx in intact cells also can mediate its effects in permeabilized cells.

\section{Inhibition of secretion in permeabilized cells by overexpressed CIRL}

The results of the previous experiment were complicated by an unexpected finding. In addition to the shift in the sensitivity to $\alpha$-Ltx, $\mathrm{Ca}^{2+}$-stimulated secretion in the absence of $\alpha$-Ltx was reduced significantly in CIRL-transfected cells, as compared with cells expressing the control plasmid pCMVneo (see legend to Fig. $5)$. The inhibition is shown clearly in Figure $6 A$, in which we asked whether the effects of CIRL could be altered by varying the concentration of $\mathrm{Ca}^{2+}$. Expression of CIRL inhibited secretion in the absence of $\alpha$-Ltx throughout a range (1-1000 $\mu \mathrm{M})$ of $\mathrm{Ca}^{2+}$ concentrations (Fig. 6A). In this experiment the expression of CIRL inhibited $\mathrm{Ca}^{2+}$-stimulated release (the difference between release in the presence of $\mathrm{Ca}^{2+}$ and release in the absence of $\mathrm{Ca}^{2+}$ ) by $56 \%$ at $1 \mu \mathrm{M} \mathrm{Ca}^{2+}$ and by $44 \%$ at $1 \mathrm{mM} \mathrm{Ca}^{2+}$.

We have demonstrated previously that different steps become rate-limiting as secretion proceeds (Holz et al., 1989; Bittner and Holz, 1992a,b). We thus determined the time course of secretion in permeabilized cells with and without overexpressed CIRL (Fig. 7). Overexpressed CIRL strongly inhibited the secretory response during the first $2 \mathrm{~min}$ after the addition of $\mathrm{Ca}^{2+}$, reducing hGH secretion by $66 \%$. In contrast, later rates of secretion were not inhibited. For example, rates of secretion for cells with and without overexpressed CIRL were 1.65 and $4.89 \%$ $\min ^{-1}$, respectively, during the first $2 \mathrm{~min}$ of the $\mathrm{Ca}^{2+}$ stimulus, but the rates were 0.34 and $0.38 \% \mathrm{~min}^{-1}$, respectively, between 6 

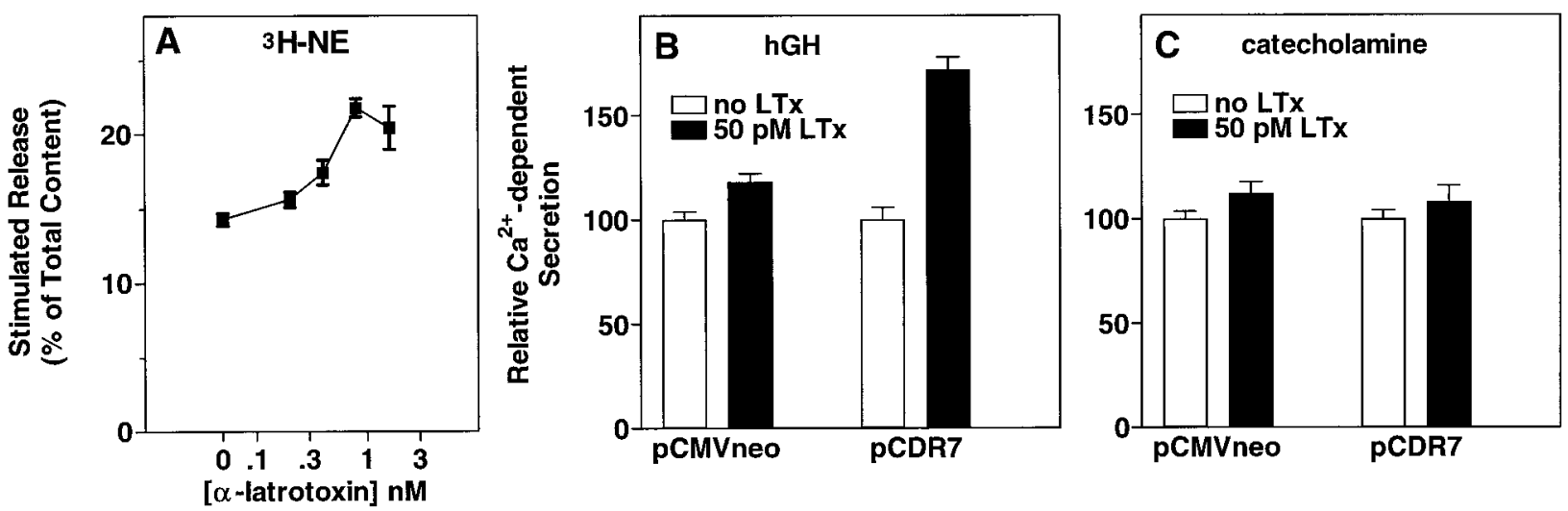

Figure 5. Expression of CIRL increases the sensitivity of permeabilized chromaffin cells to the secretion-enhancing effects of $\alpha$-Ltx. $A$, Monolayer cultures of nontransfected chromaffin cells were labeled with ${ }^{3} \mathrm{H}$-norepinephrine $\left({ }^{3} \mathrm{H}-\mathrm{NE}\right)$, rinsed, and incubated with the indicated concentrations of $\alpha$-Ltx in physiological saline without $\mathrm{Ca}^{2+}$ or $\mathrm{Mg}^{2+}$ and with $0.2 \mathrm{~mm}$ EGTA for $4 \mathrm{~min}$. The toxin was removed, and the cells were permeabilized for 6 min in KGEP buffer containing $20 \mu \mathrm{M}$ digitonin and $2 \mathrm{mM} \mathrm{MgATP}$, followed by incubation with or without $30 \mu \mathrm{M} \mathrm{Ca}{ }^{2+}$ in KGEP with 2 mM MgATP for $16 \mathrm{~min}$. The incubation solution was removed, the cells were lysed with $1 \%$ Triton X-100, and the amount of ${ }^{3} \mathrm{H}-\mathrm{NE}$ was determined by liquid scintillation spectrometry. $B, C$, Chromaffin cells were transfected with plasmids for hGH (pXGH5) and either pCDR7 or pCMVneo, as in Figure 2. After 4-6 d the cells were incubated with the indicated concentrations of $\alpha$-Ltx in PSS without $\mathrm{Ca}^{2+} \operatorname{or~Mg}^{2+}$ and with 0.1 mM EGTA. After 4 min the toxin was removed, and the cells were permeabilized with $20 \mu \mathrm{M}$ digitonin in KGEP buffer without $\mathrm{Ca}^{2+}$ for 4 min, followed by incubation with or without $30 \mu \mathrm{M} \mathrm{Ca}^{2+}$ in KGEP for $15 \mathrm{~min}$. MgATP $(2 \mathrm{mM})$ was included in both incubations. The amounts of hGH $(B)$ and catecholamine $(C)$ released into the medium and the amounts remaining in the cells were determined as described. For each condition ( \pm CIRL), release in the presence of $\alpha$-Ltx was normalized to release in the absence of toxin. Actual values for $\mathrm{Ca}^{2+}$-dependent release of hGH in the absence of $\alpha$-Ltx were $21.38 \pm 0.80 \%$ $(p C M V n e o)$ and $15.75 \pm 1.78 \%(p C D R 7 ; p<0.05$ vs $p C M V n e o)$. Values for $\mathrm{Ca}^{2+}$-dependent release of catecholamine were $17.15 \pm 0.59 \%(p C M V n e o)$ and $17.49 \pm 0.72 \%(p C D R 7) ; n=4$ wells/group.
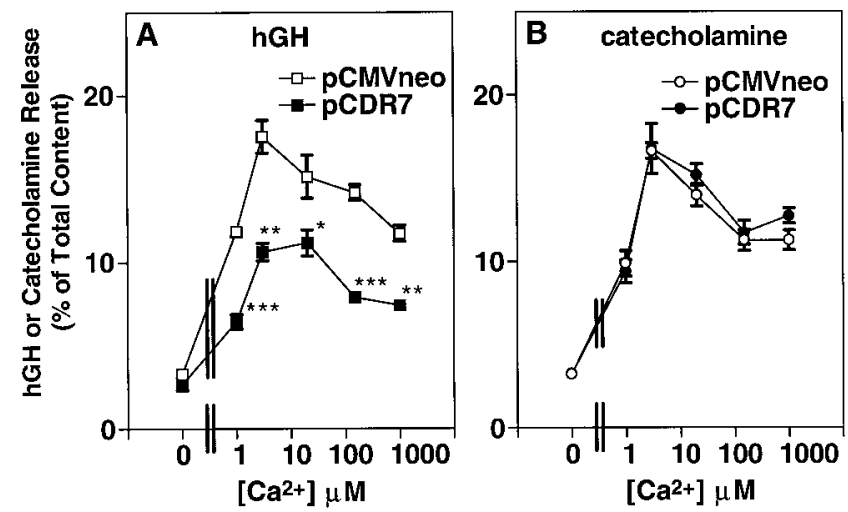

Figure 6. Expression of CIRL reduces secretion at all $\mathrm{Ca}^{2+}$ concentrations. Chromaffin cells were transfected with plasmids for hGH (pXGH5) and either pCDR7 or pCMVneo, as in Figure 2. After $4 \mathrm{~d}$ the cells were permeabilized with $20 \mu \mathrm{M}$ digitonin in KGENP buffer (potassium glutamate, EGTA, nitrilotriacetic acid, and PIPES-containing solution; see Materials and Methods) without $\mathrm{Ca}^{2+}$ for 4 min, followed by incubation with the indicated $\mathrm{Ca}^{2+}$ concentrations in KGENP for 15 min. MgATP $(2 \mathrm{mM})$ was included in both incubations. The amounts of hGH $(A)$ and catecholamine $(B)$ released into the medium and the amounts remaining in the cells were determined as described; $n=4$ wells/group. ${ }^{*} p<0.05$ versus pCMVneo; ${ }^{* *} p<0.001$ versus pCMVneo; ${ }^{* *} p<0.0001$ versus pCMVneo.

and $15 \mathrm{~min}$. This suggests the possibility that CIRL is inhibiting a specific step in the secretory pathway.

\section{Specificity of the inhibition by overexpressed CIRL}

During the first few minutes of a $\mathrm{Ca}^{2+}$ stimulus, two components of secretion are present. One component does not require the presence of MgATP and has been termed "primed" secretion. It is likely that this secretion reflects the previous action of ATP in intact cells before permeabilization (Holz et al., 1989). The

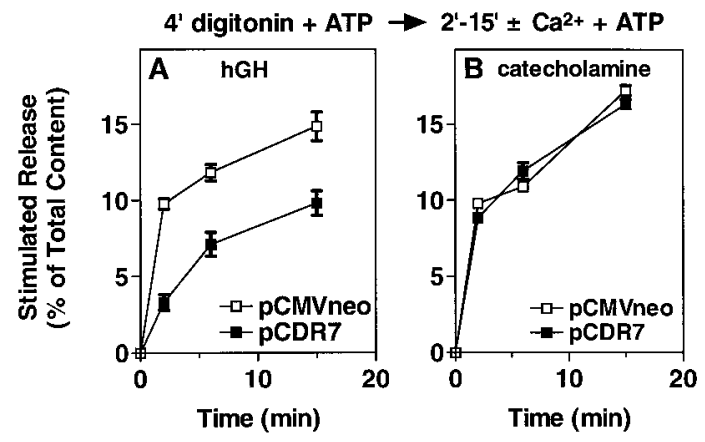

Figure 7. Time course of secretion in permeabilized chromaffin cells with or without overexpressed CIRL. Chromaffin cells were transfected with plasmids for hGH (pXGH5) and either pCDR7 or pCMVneo, as in Figure 2. After $4 \mathrm{~d}$ the cells were permeabilized with $20 \mu \mathrm{M}$ digitonin in KGEP buffer without $\mathrm{Ca}^{2+}$ and with $2 \mathrm{~mm} \mathrm{MgATP}$ for 4 min, followed by incubation with or without $30 \mu \mathrm{M} \mathrm{Ca}{ }^{2+}$ in KGEP containing $2 \mathrm{~mm}$ MgATP for the indicated times. The amounts of hGH $(A)$ and catecholamine $(B)$ released into the medium and the amounts remaining in the cells were determined as described; $n=4$ wells/group.

second component requires the continuing presence of MgATP. The steps are summarized as:

$$
\begin{aligned}
& \text { Unprimed } \rightarrow \rightarrow \text { Primed } \rightarrow \text { Exocytosis } \\
& \uparrow \text { ATP } \quad \uparrow \mathrm{Ca}^{2+}
\end{aligned}
$$

We asked whether the inhibition by CIRL could be localized to a particular step in the secretory pathway. Cells transfected with or without CIRL were permeabilized for $4 \mathrm{~min}$ in the presence or absence of $2 \mathrm{~mm}$ MgATP and then were stimulated with $30 \mu \mathrm{M}$ $\mathrm{Ca}^{2+}$ for $2 \mathrm{~min}$. The ATP-dependent component of secretion was strongly inhibited, whereas ATP-independent secretion was unchanged (Fig. 8A). This result suggests that CIRL inhibits an early step in the ATP-dependent priming pathway and that se- 


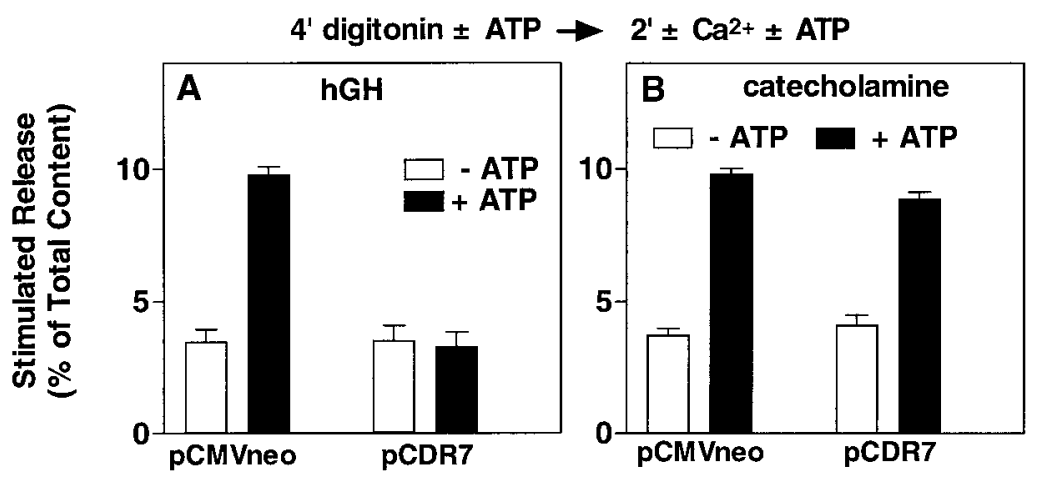

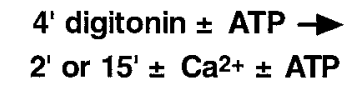

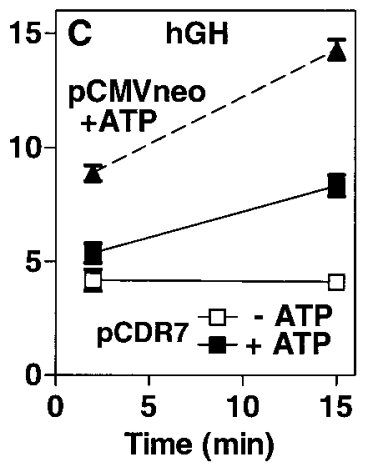

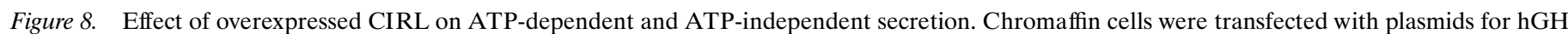

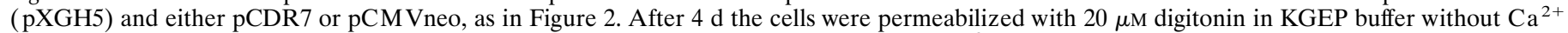

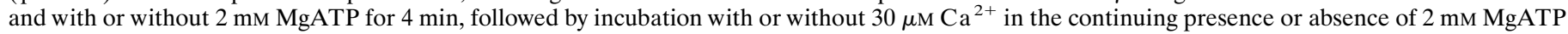

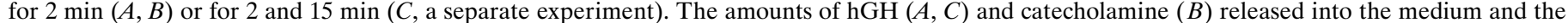
amounts remaining in the cells were determined as described; $n=4$ wells/group.

cretory granules that have been primed by ATP are insensitive to inhibition by CIRL.

In conjunction with the previous experiment the profound inhibition of ATP-dependent secretion by CIRL raises another question. CIRL strongly inhibited ATP-dependent priming (Fig. $8 A$ ), yet after 2 min [a time when secretion in nontransfected cells is completely dependent on ATP (Holz et al., 1989)] the rates of secretion in CIRL-transfected cells were comparable to those in control cells (see Fig. 7). We thus asked whether the continuing secretion in the presence of CIRL was ATP-dependent. Cells transfected with CIRL were permeabilized for 4 min with or without $2 \mathrm{~mm} \mathrm{MgATP}$ and then were stimulated with $30 \mu \mathrm{M} \mathrm{Ca}^{2+}$ for 2 or $15 \mathrm{~min}$ in the continuing presence or absence of MgATP (Fig. 8C). For comparison, cells transfected without CIRL were stimulated to secrete in the presence of MgATP. Again, the expression of CIRL inhibited ATP-dependent secretion at 2 min. ATP-independent secretion in cells with CIRL did not increase between 2 and $15 \mathrm{~min}$; rather, just as in cells that received the control plasmid, secretion continued in CIRL-expressing cells only if ATP was present. We thus conclude that the block in ATP-dependent priming by CIRL is partial rather than complete and probably represents a slowing of a discrete ATP-dependent step in the pathway. At later times another step becomes ratelimiting, and the amount of priming permitted by transfected CIRL is sufficient to maintain the ATP-dependent secretory response.

In Figure $8 A$, we showed that CIRL had no effect on the ATP-independent component of secretion. Because the amount of ATP-independent secretion is small with that experimental protocol, a second protocol was used to confirm this conclusion. In the previous experiments (see Figs. 5-8) cells were permeabilized for 4 min before the addition of $\mathrm{Ca}^{2+}$ to stimulate secretion. An alternative protocol is to add $\mathrm{Ca}^{2+}$ together with digitonin. This latter protocol elicits an extensive secretory response that is, in large part, ATP-independent; that is, for a period of several minutes, secretion cannot be augmented by adding MgATP. In Figure $9 A$, we compared secretion from chromaffin cells transfected with or without CIRL, using a protocol in which the $\mathrm{Ca}^{2+}$ stimulus $\left(30 \mu \mathrm{M} \mathrm{Ca}^{2+}\right)$ is included in the permeabilization solution. The incubation was done in both the presence and absence of $2 \mathrm{~mm} \mathrm{MgATP}$. Under these conditions, which strongly empha-
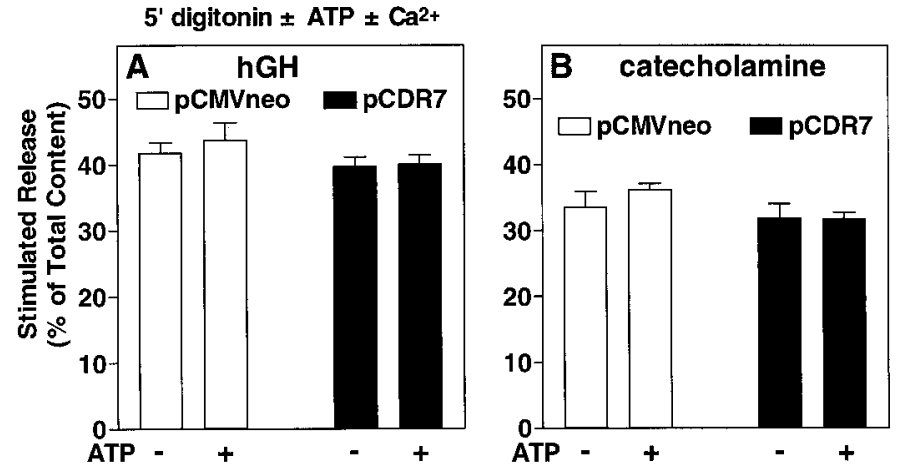

Figure 9. Effect of overexpressed CIRL on secretion stimulated in the presence of digitonin with and without exogenous ATP. Chromaffin cells were transfected with plasmids for hGH (pXGH5) and either pCDR7 or pCMVneo, as in Figure 2. After 6 d the cells were permeabilized with 20 $\mu \mathrm{M}$ digitonin in KGEP buffer with or without $30 \mu \mathrm{M} \mathrm{Ca}{ }^{2+}$ and with or without $2 \mathrm{~mm} \mathrm{MgATP}$ for $5 \mathrm{~min}$. The amounts of $\mathrm{hGH}(A)$ and catecholamine $(B)$ released into the medium and the amounts remaining in the cells were determined as described; $n=4$ wells/group.

sized the ATP-independent component of secretion, overexpressed CIRL did not inhibit secretion (Fig. 9A). Thus, as in the previous experiment, ATP-independent secretion was resistant to inhibition by CIRL. The secretory response using this protocol was large; $>40 \%$ of the total hGH content was released during the 5 min incubation. This rules out the possibility that the inhibition by overexpressed CIRL is attributable to a nonspecific toxic effect of the overexpressed protein. On the contrary, the effect seems to be highly specific and occurs only when the cells are forced to demonstrate rapid ATP-dependent secretion.

In a previous study we demonstrated that CIRL appears to be a novel G-protein-coupled receptor of the secretin receptor family. To establish further the specific nature of the inhibition by CIRL, we examined the effects of overexpressing two other G-protein-coupled receptors. The bombesin receptor, which is coupled to $\mathrm{G}_{\mathrm{q}}$, and the $\alpha_{2}$-adrenergic receptor, which couples to $\mathrm{G}_{\mathrm{i}}$, were each overexpressed in chromaffin cells (Fig. 10). Unlike overexpressed CIRL, neither the bombesin nor the $\alpha_{2}$ receptor inhibited secretion in permeabilized cells (Fig. 10A). Expression of active bombesin receptor was confirmed by the fact that it 

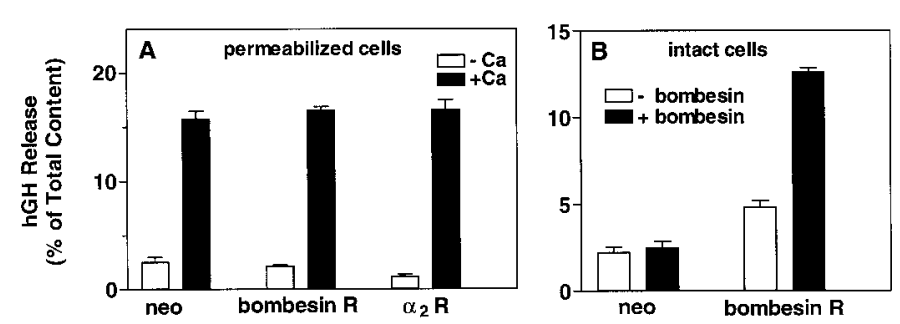

Figure 10. Effect of overexpressed G-protein-coupled receptors on secretion from digitonin-permeabilized chromaffin cells. Chromaffin cells were transfected with plasmids for hGH (pXGH5) and the $\alpha_{2}$ adrenergic receptor, the bombesin receptor, or pCMVneo, as in Figure 2. After $4 \mathrm{~d}$ the cells were permeabilized $(A)$ with $20 \mu \mathrm{M}$ digitonin in KGEP buffer without $\mathrm{Ca}^{2+}$ and with $2 \mathrm{mM} \mathrm{MgATP}$ for $4 \mathrm{~min}$, followed by incubation with or without $30 \mu \mathrm{M} \mathrm{Ca}^{2+}$ in KGEP containing $2 \mathrm{~mm} \mathrm{MgATP}$ for $2 \mathrm{~min}$. $B$, Intact cells transfected with either pCMVneo or bombesin receptor were challenged for $12 \mathrm{~min}$ with $20 \mathrm{nM}$ bombesin in PSS containing 2.2 $\mathrm{mM} \mathrm{Ca}{ }^{2+}$ and $0.5 \mathrm{mM} \mathrm{Mg}^{2+}$. The amounts of hGH and catecholamine (data not shown) released into the medium and the amounts remaining in the cells were determined as described; $n=4$ wells/group.

rendered the transfected cells sensitive to bombesin (Fig. 10B). In addition, the expression of both receptors was confirmed on protein blots. This result demonstrates that the inhibitory effect of CIRL is not a common property of overexpression of G-proteinlinked receptors but rather reflects a specific effect of CIRL.

\section{DISCUSSION}

In an earlier study that described the cloning of a $\mathrm{Ca}^{2+}$ independent receptor for $\alpha$-Ltx (Krasnoperov et al., 1997), we demonstrated that overexpression of CIRL in chromaffin cells rendered them more sensitive to stimulation by the toxin. This was the first demonstration that directly linked a specific $\alpha$-Ltx binding protein with secretion. The current study extends that finding. It demonstrates that CIRL both mediates $\alpha$-Ltxmediated $\mathrm{Ca}^{2+}$ uptake and modulates secretion in the absence of $\alpha$-Ltx at a step after $\mathrm{Ca}^{2+}$ entry. Before we discuss the effects of transfected CIRL, it is important to consider the effects of $\alpha$-Ltx on nontransfected cells.

\section{Effects of $\alpha$-Ltx on secretion from nontransfected cells}

Secretion stimulated by $\alpha$-Ltx from nontransfected chromaffin cells was associated with ${ }^{45} \mathrm{Ca}^{2+}$ uptake (see Fig. 1). Although extracellular $\mathrm{Ca}^{2+}$ was required for secretion, the response occurred after $\alpha$-Ltx had been incubated with the cells in the absence of divalent ions (+EGTA) and then removed. Thus, $\alpha$-Ltx caused its effects by binding to endogenous receptors in the absence of $\mathrm{Ca}^{2+}$. The ability of $\alpha$-Ltx to stimulate $\mathrm{Ca}^{2+}$ influx and secretion in chromaffin cells is consistent with an electrophysiological study in rat chromaffin cells in which a nonspecific ionic conductance induced by $\alpha$-Ltx correlated with the stimulation of secretion (Barnett et al., 1996).

A striking finding was the ability of previous incubation of intact cells with $\alpha$-Ltx (in the absence of divalent ions) to enhance $\mathrm{Ca}^{2+}$-dependent secretion from subsequently permeabilized cells. This suggests that the endogenous receptor for $\alpha$-Ltx modulates a step in the secretory pathway after $\mathrm{Ca}^{2+}$ entry. Indeed, transfected CIRL modulates secretion in digitoninpermeabilized cells even in the absence of $\alpha$-Ltx (discussed below).

\section{Transfected CIRL increases the sensitivity of cells to the effects of $\alpha$-Ltx on $\mathrm{Ca}^{2+}$ permeability and secretion}

Previously, we showed that expression of CIRL increased the sensitivity of chromaffin cells to stimulation by $\alpha$-Ltx (Krasnoperov et al., 1997). Here we demonstrate that the interaction of $\alpha$-Ltx with its cloned receptor increases $\mathrm{Ca}^{2+}$ permeability and resulting secretion. In the present study we find that chromaffin cells transiently transfected with CIRL are 10 -fold more sensitive than nontransfected cells to the stimulation of $\mathrm{Ca}^{2+}$-dependent secretion by $\alpha$-Ltx. Importantly, at least one of the mechanisms responsible for this secretion is an increase in cytosolic $\mathrm{Ca}^{2+}$ (see Fig. 4C). Furthermore, using HEK293 cells that transiently express CIRL, we establish directly that the interaction of $\alpha$-Ltx with CIRL results in $\mathrm{Ca}^{2+}$ influx (see Fig. $4 A$ ). This increase in $\mathrm{Ca}^{2+}$ permeability could result from the channel-forming ability of the toxin while it is tethered to the receptor or from activation of the receptor.

Besides stimulating intact chromaffin cells, $\alpha$-Ltx also enhances secretion in permeabilized cells (see above). Transient expression of CIRL increased the sensitivity of permeabilized cells as well as of intact cells to $\alpha$-Ltx. Thus, the same protein that mediates $\alpha$-Ltx effects in intact cells mediates the effects of the toxin in digitonin-permeabilized cells.

\section{Similarities between endogenous receptor and transfected CIRL}

The properties of transiently expressed CIRL closely resemble those of the endogenous latrotoxin receptor. Binding of $\alpha$-Ltx to both proteins is $\mathrm{Ca}^{2+}$-independent and occurs in the presence of EGTA. Association of $\alpha$-Ltx with the endogenous (see Figs. 1, 4) or transfected (see Fig. 4) receptor gives rise to a large influx of extracellular $\mathrm{Ca}^{2+}$, which in both cases occurs after a delay of 2-4 min. Secretion stimulated by the interaction of $\alpha$-Ltx with either receptor is strongly dependent on extracellular $\mathrm{Ca}^{2+}$ (see Fig. 3). Expression of CIRL increases the sensitivity of the cells to $\alpha$-Ltx without increasing the maximal secretory response, a result consistent with a simple increase in receptor number. Both endogenous and transfected receptors mediate the effects of $\alpha$-Ltx in digitonin-permeabilized as well as in intact chromaffin cells (see Fig. 5). The endogenous chromaffin cell receptor is a glycoprotein, as predicted from the structure of CIRL (our unpublished data). Finally, an antibody (Krasnoperov et al., 1997) to an 18-amino-acid peptide of the $\mathrm{C}$ terminus of the cloned receptor recognizes a chromaffin cell protein of the appropriate molecular weight. With the exception of an absolute requirement for $\mathrm{Ca}^{2+}$ during secretion (discussed below), the characteristics of the response of the endogenous and transfected receptor to $\alpha$-Ltx in chromaffin cells are consistent with work done in other systems.

While this manuscript was being submitted, a report appeared (Michelena et al., 1997) describing the effects of $\alpha$-Ltx on bovine chromaffin cells, effects which are in contrast with our observations and those of a previous study (Barnett et al., 1996). The authors found that high concentrations of $\alpha$-Ltx (5-15 times higher than those used here) caused a small and reversible enhancement of secretion that was not associated with $\mathrm{Ca}^{2+}$ influx or a detectable rise in cytosolic $\mathrm{Ca}^{2+}$. It was concluded that the effects of $\alpha$-Ltx were not mediated by a specific receptor, and reference was made to unsuccessful attempts to identify a receptor in chromaffin cells. It is indeed likely that their preparation of chromaffin cells did not have the endogenous receptor. $\alpha$-Ltx binding sites are sensitive to trypsin (Meldolesi et al., 1983), and 
there is evidence that $\alpha$-Ltx receptors increase with time in culture after cell preparation (Surkova, 1994), suggesting that receptors are lost during cell dissociation with proteases. Our experiments were performed at least $5 \mathrm{~d}$ after cell preparation, using monolayer cultures rather than suspended cells. As indicated above, our procedures allow us to identify an endogenous receptor similar to CIRL in bovine chromaffin cells.

\section{$\mathrm{Ca}^{2+}$ independence of $\alpha$-Ltx effects: binding versus secretion}

The ability of $\alpha$-Ltx to evoke secretion in the absence of $\mathrm{Ca}^{2+}$, a striking property of the neuromuscular junction (Fesce et al., 1986) and central synapses (Capogna et al., 1996), is not manifest in chromaffin cells. In chromaffin cells virtually no $\mathrm{Ca}^{2+}$ independent secretion is stimulated by $\alpha$-Ltx if $\mathrm{Ca}^{2+}$ is strongly chelated. We find that, in the nominal absence of $\mathrm{Ca}^{2+}$ without EGTA and with millimolar $\mathrm{Mg}^{2+}$, secretion stimulated by $\alpha$-Ltx may be $15-20 \%$ of cell catecholamine. This secretion is abolished completely by the addition of sufficient EGTA, even in the continuing presence of $\mathrm{Mg}^{2+}$ (data not shown). Thus, although binding to either the endogenous receptor or to transiently expressed CIRL takes place when $\mathrm{Ca}^{2+}$ is strongly chelated, subsequent secretion depends completely on external $\mathrm{Ca}^{2+}$. It is possible that in some studies the " $\mathrm{Ca}^{2+}$-independent" effect of $\alpha$-Ltx at nerve terminals was a result of residual $\mathrm{Ca}^{2+}$. Alternatively, the difference between $\alpha$-Ltx effects at nerve terminals and its effects on neuroendocrine cells may result from (1) different endogenous receptors or (2) differences in the way the receptor couples to the secretory compartments being studied. Given that $\alpha$-Ltx is unable to stimulate significant $\mathrm{Ca}^{2+}$-independent secretion in chromaffin cells transfected with CIRL that was cloned from brain (see Fig. 3), the latter possibility seems to be the most likely.

\section{The effect of transfected CIRL on secretion from permeabilized cells indicates a role in the secretory pathway}

An unexpected and important finding was that transfected CIRL modulated the secretory pathway independently of $\alpha$-Ltx. Overexpressed CIRL inhibited $\mathrm{Ca}^{2+}$-stimulated secretion in permeabilized cells, an effect that must involve the secretory machinery at a step other than the $\mathrm{Ca}^{2+}$ signal. The inhibition was highly specific for a particular step in the pathway, being limited to the initial, rapid phase of ATP-dependent secretion. This suggests that CIRL specifically regulates a rate-limiting step in ATPdependent priming. This result was particularly striking in that only the most rapid ATP-dependent secretion (that occurring within 2 min of the onset of stimulation) was inhibited. Later, slower ATP-dependent secretion was unaltered. The result suggests that CIRL regulates secretion by slowing rather than abolishing the ATP-dependent priming pathway.

This inhibitory effect of CIRL on secretion is not common to other G-protein-linked receptors. No inhibition of secretion was observed when either the $\alpha_{2}$-adrenergic or the bombesin receptor was transiently expressed in chromaffin cells.

On the basis of the ability of the overexpressed protein to inhibit secretion, we speculate that CIRL may be a constitutively active receptor, the normal function of which is to reduce secretion. As a corollary, the enhancement of secretion produced by $\alpha$-Ltx in nontransfected, permeabilized cells might be attributable to the toxin antagonizing the inhibitory effect of the receptor. Although we do not yet know the details of the mechanism by which the inhibition occurs, structural and biochemical properties of the receptor [e.g., interaction with syntaxin or G-proteins (Krasnoperov et al., 1997)] may provide important clues to its function. The fact that CIRL and syntaxin can be coimmunoprecipitated (Krasnoperov et al., 1997) means that CIRL can interact with a protein that is known to play a role in regulated secretion. An interaction with syntaxin may underlie some of the effects of the receptor on secretion.

The endogenous ligand for CIRL is unknown. It may function similarly to $\alpha$-Ltx to stimulate secretion via an increase in $\mathrm{Ca}^{2+}$ influx and/or via direct stimulation of the secretory machinery. However, the endogenous ligand may have an effect completely different from that of $\alpha$-Ltx. Instead of stimulating secretion, it could accentuate the constitutive activity of the receptor to inhibit secretion. In either case it is likely that the endogenous ligand acting via CIRL will have an important presynaptic effect to regulate synaptic transmission.

\section{REFERENCES}

Barnett DW, Liu J, Misler S (1996) Single-cell measurements of quantal secretion induced by $\alpha$-latrotoxin from rat adrenal chromaffin cells: dependence on extracellular $\mathrm{Ca}^{2+}$. Pflügers Arch 432:1039-1046.

Battey JF, Way JM, Corjay MH, Shapira H, Kusano K, Harkins R, Wu JM, Slattery T, Mann E, Feldman RI (1991) Molecular cloning of the bombesin/gastrin-releasing peptide receptor from Swiss 3T3 cells. Proc Natl Acad Sci USA 88:395-399.

Bittner MA, Holz RW (1992a) A temperature-sensitive step in exocytosis. J Biol Chem 267:16226-16229.

Bittner MA, Holz RW (1992b) Kinetic analysis of secretion from permeabilized adrenal chromaffin cells reveals distinct components. J Biol Chem 267:16219-16225.

Bittner MA, Bennett MK, Holz RW (1996) Evidence that syntaxin 1A is involved in storage in the secretory pathway. $J$ Biol Chem 271:11214-11221.

Capogna M, Gahwiler BH, Thompson SM (1996) Calcium-independent actions of $\alpha$-latrotoxin on spontaneous and evoked synaptic transmission in the hippocampus. J Neurophysiol 76:3149-3158.

Ceccarelli B, Hurlbut WP (1980) $\mathrm{Ca}^{2+}$-dependent recycling of synaptic vesicles at the frog neuromuscular junction. J Cell Biol 87:297-303.

Chung S-H, Takai Y, Holz RW (1995) Evidence that the rab3a-binding protein, rabphilin3a, enhances regulated secretion: studies in adrenal chromaffin cells. J Biol Chem 270:16714-16718.

Davletov BA, Shamotienko OG, Lelianova VG, Grishin EV, Ushkaryov YA (1996) Isolation and biochemical characterization of a $\mathrm{Ca}^{2+}$ independent $\alpha$-latrotoxin-binding protein. J Biol Chem 271: 23239-23245.

Dunn LA, Holz RW (1983) Catecholamine secretion from digitonintreated adrenal medullary chromaffin cells. $\mathrm{J}$ Biol Chem 258:4989-4993.

Fesce R, Segal JR, Ceccarelli B, Hurlbut WP (1986) Effects of black widow spider venom and $\mathrm{Ca}^{2+}$ on quantal secretion at the frog neuromuscular junction. J Gen Physiol 88:59-81.

Finkelstein A, Rubin LL, Tzeng M-C (1976) Black widow spider venom: effect of purified toxin on lipid bilayer membranes. Science 193:1009-1011.

Grynkiewicz G, Poenie M, Tsien RY (1985) A new generation of calcium indicators with greatly improved fluorescence properties. J Biol Chem 260:3440-3454.

Helm R, Cubitt AB, Tsien RY (1995) Improved green fluorescence. Nature 373:663-664.

Holz RW, Bittner MA, Peppers SC, Senter RA, Eberhard DA (1989) MgATP-independent and MgATP-dependent exocytosis. Evidence that MgATP primes adrenal chromaffin cells to undergo exocytosis. J Biol Chem 264:5412-5419.

Holz RW, Brondyk WH, Senter RA, Kuizon L, Macara IG (1994) Evidence for the involvement of Rab3a in $\mathrm{Ca}^{2+}$-dependent exocytosis from adrenal chromaffin cells. J Biol Chem 269:10229-10234.

Keefer JR, Limbird LE (1993) The $\alpha_{2 \mathrm{~A}}$-adrenergic receptor is targeted directly to the basolateral membrane domain of Madin-Darby canine kidney cells independent of coupling to pertussis toxin-sensitive GTPbinding proteins. J Biol Chem 268:11340-11347. 
Knight DE, Baker PF (1982) Calcium dependence of catecholamine release from bovine adrenal medullary cells after exposure to intense electric fields. J Membr Biol 68:107-140.

Krasnoperov VG, Beavis R, Chepurny OG, Little AR, Plotnikov AN, Petrenko AG (1996) The calcium-independent receptor of $\alpha$ latrotoxin is not a neurexin. Biochem Biophys Res Commun $227: 868-875$.

Krasnoperov VG, Bittner MA, Beavis R, Kuang Y, Salnikow KV, Chepurny OG, Little AR, Plotnikov AN, Wu D, Holz RW, Petrenko AG (1997) $\alpha$-Latrotoxin stimulates exocytosis by the interaction with a neuronal G-protein-coupled receptor. Neuron 18:925-937.

Lelianova VG, Davletov BA, Sterling A, Rahman MA, Grishin EV, Totty NF, Ushkaryov YA (1997) $\alpha$-Latrotoxin receptor, latrophilin, is a novel member of the secretin family of G-protein-coupled receptors. J Biol Chem 272:21504-21508.

Longenecker HE, Hurlbut WP, Mauro A, Clark AW (1970) Effects of black widow spider venom on the frog neuromuscular junction. Nature 225:701-703.

Ma W-J, Holz RW, Uhler MD (1992) Expression of a cDNA for a neuronal calcium channel $\alpha 1$ subunit enhances secretion from adrenal chromaffin cells. J Biol Chem 267:22728-22732.

McMahon HT, Rosenthal L, Meldolesi J, Nicholls DG (1990) $\alpha$-Latrotoxin releases both vesicular and cytoplasmic glutamate from isolated nerve terminals. J Neurochem 55:2039-2047.

Meldolesi J, Madeddu L, Torda M, Gatti G, Niutta E (1983) The effect of $\alpha$-latrotoxin on the neurosecretory PC12 cell line: studies on toxin binding and stimulation of transmitter release. Neuroscience 10:997-1009.

Meldolesi J, Huttner WB, Tsien RY, Pozzan T (1984) Free cytoplasmic $\mathrm{Ca}^{2+}$ and neurotransmitter release: studies on PC12 cells and synaptosomes exposed to $\alpha$-latrotoxin. Proc Natl Acad Sci USA 81:620-624.

Michelena P, de la Fuente MT, Vega T, Lara B, Lopez MG, Gandia L, Garcia AG (1997) Drastic facilitation by $\alpha$-latrotoxin of bovine chromaffin cell exocytosis without measurable enhancement of $\mathrm{Ca}^{2+}$ entry or $\left[\mathrm{Ca}^{2+}\right]_{\mathrm{i}}$. J Physiol (Lond) 502:481-496.

Petrenko AG, Kovalenko VA, Shamotienko OG, Surkova IN, Tarasyuk
TA, Ushkaryov YA, Grishin EV (1990) Isolation and properties of the $\alpha$-latrotoxin receptor. EMBO J 9:2023-2027.

Petrenko AG, Lazaryeva VD, Geppert M, Tarasyuk TA, Moomaw C, Khokhlatchev AV, Ushkaryov YA, Slaughter C, Nasimov IV, Sudhof TC (1993) Polypeptide composition of the $\alpha$-latrotoxin receptor. High affinity binding protein consists of a family of related high molecular weight polypeptides complexed to a low molecular weight protein. J Biol Chem 268:1860-1867.

Pumplin DW, Reese TS (1977) Action of brown widow spider venom and botulinum toxin on the frog neuromuscular junction examined with the freeze-fracture technique. J Physiol (Lond) 273:443-457.

Rosenthal L, Zacchetti D, Madeddu L, Meldolesi J (1990) Mode of action of $\alpha$-latrotoxin: role of divalent cations in $\mathrm{Ca}^{2+}$-dependent and $\mathrm{Ca}^{2+}$-independent effects mediated by the toxin. Mol Pharmacol 38:917-923.

Selden RF, Howie KB, Rowe ME, Goodman HM, Moore DD (1986) Human growth hormone as a reporter gene in regulation studies employing transient gene expression. Mol Cell Biol 6:3173-3179.

Stuenkel EL, Nordmann JJ (1993) Intracellular calcium and vasopressin release from rat isolated neurohypophysial nerve endings. J Physiol (Lond) 468:335-365.

Surkova I (1994) Can exocytosis induced by $\alpha$-latrotoxin be explained solely by its channel-forming activity? Ann NY Acad Sci 710:48-64.

Tseng M-J, Detjen K, Struk V, Logsdon CD (1995) Carboxyl-terminal domains determine internalization and recycling characteristics of bombesin receptor chimeras. J Biol Chem 270:18858-18864.

Ushkaryov YA, Petrenko AG, Geppert M, Sudhof TC (1992) Neurexins: synaptic cell surface proteins related to the $\alpha$-latrotoxin receptor and laminin. Science 257:50-56.

Wick PW, Senter RA, Parsels LA, Holz RW (1993) Transient transfection studies of secretion in bovine chromaffin cells and PC12 cells: generation of kainate-sensitive chromaffin cells. J Biol Chem 268:10983-10989.

Wilson SP, Liu F, Wilson RE, Housley PR (1996) Optimization of calcium phosphate transfection for bovine chromaffin cells: relationship to calcium phosphate precipitate formation. Anal Biochem 226:212-220. 